Article

\title{
Description of Aurelia pseudosolida sp. nov. (Scyphozoa, Ulmaridae) from the Adriatic Sea
}

\author{
Rade Garić (D) and Mirna Batistić *
}

Citation: Garić, R.; Batistić, M. Description of Aurelia pseudosolida sp. nov. (Scyphozoa, Ulmaridae) from the Adriatic Sea. Water 2022, 14, 135 https://doi.org/10.3390/w14020135 Academic Editor: Arantza Iriarte

Received: 4 November 2021

Accepted: 3 January 2022

Published: 6 January 2022

Publisher's Note: MDPI stays neutral with regard to jurisdictional claims in published maps and institutional affiliations.

Copyright: (C) 2022 by the authors. Licensee MDPI, Basel, Switzerland. This article is an open access article distributed under the terms and conditions of the Creative Commons Attribution (CC BY) license (https:// creativecommons.org/licenses/by/ $4.0 /)$.
Institute for Marine and Coastal Research, University of Dubrovnik, Kneza Damjana Jude 12, 20000 Dubrovnik, Croatia; rade.garic@unidu.hr

* Correspondence: mirna.batistic@unidu.hr

\begin{abstract}
Until 2021, the genus Aurelia contained eleven described species (WoRMS, 2020), with many genetic species still awaiting a formal description. In 2021, ten new species of Aurelia were described almost solely from genetic data in a novel attempt to use genetic characters as diagnostic characters for species descriptions, leaving seven genetic species still undescribed. Here we present the description of a new Aurelia species from the Adriatic Sea using an integrative taxonomy approach, i.e., employing molecular as well as morphological characteristics in order to describe this new Aurelia species. The species is described based on a single medusa sampled from the town of Rovinj (Croatia), North Adriatic, amidst combined blooms of the ctenophore Mnemiopsis leidy and cnidarian Aurelia solida in the summer of 2020. Based on genetic data, the newly described Aurelia pseudosolida sp. nov. has never been sequenced in any of the previous investigations of the molecular diversity of Aurelia. This is the second species belonging to Discomedusae described from the North Adriatic in little more than half a decade, which could be yet another indication of the susceptibility of the North Adriatic to proliferation of non-indigenous gelatinous species, especially if we take into account historical as well as recent blooms of suspected non-indigenous gelatinous species such as Muggiaea atlantica, Aurelia solida, Mawia benovici and Mnemiopsis leidy.
\end{abstract}

Keywords: Adriatic Sea; Aurelia pseudosolida; Aurelia solida; Mnemiopsis leidy; integrative taxonomy; gelatinous zooplankton; zooplankton bloom

\section{Introduction}

Aurelia species are known for their boom and bust population dynamics, when during the bloom (boom) phase they form large swarms affecting ecosystems, fisheries and tourism [1-5]. In the Mediterranean there have been, so far, four recorded species: Aurelia aurita, Aurelia coerulea, Aurelia relicta and Aurelia solida [6]. Aurelia solida is considered a Lessepsian migrant and it has established its populations in the North Adriatic with an annual occurrence [6-8]. Aurelia relicta is endemic to the Mljet lakes (Mljet island, South Adriatic) [6,9], while Aurelia aurita has been confirmed from the Black Sea and Bosporus [9]. The fourth species, $A$. coerulea, is a species confined to coastal areas in the Mediterranean, which have large fluctuations in temperature and salinity [6].

There has been a lot of confusion about how many species of Aurelia there are and if much of the proposed Aurelia species were in fact just forms of few species. The matter was mostly settled with genetic research, which revealed that there are many more Aurelia species than anticipated [7,9], opening yet another Pandora box of cryptic species. Until 2021, there were 12 described Aurelia species [10], out of which 7 were genetically characterized $[6,7,11]$. In addition to those, there were 11 Aurelia species known solely from their DNA sequences [7,9,11-14]. In 2021, ten new species of Aurelia were described by Lawley et al. [15], based mostly on genetic characters, leaving behind the traditional need for morphological diagnostic characters in order to describe new species, while four previously undescribed species were resurrected, leaving seven genetic species still undescribed. 
Here we describe a new species of Aurelia, from a single individual found in the North Adriatic in 2020. The species is morphologically and genetically distinct, with an elaborate morphology of the oral arms of the manubrium as its most prominent feature.

\section{Materials and Methods}

Aurelia solida and Aurelia pseudosolida sp. nov. specimens were collected on 27 July 2020 in Rovinj (Croatia), 45 $05^{\prime} 05.3^{\prime \prime}$ N, 013 $38^{\prime} 04.0^{\prime \prime}$ E, using hand nets (Figure 1). During collection, Aurelia solida specimens were counted from the shore in order to estimate their number. Five individuals of Aurelia solida and one individual of Aurelia pseudosolida sp. nov. were collected for genetic and morphological analysis. Due to the peculiar morphology of Aurelia pseudosolida sp. nov., two short videos were made of a living specimen at the time of collection. From each collected animal a part of the tissue was taken for DNA analysis and preserved in 100\% acetone, while the rest of the animal was preserved in 10\% formalin. From each acetone-preserved tissue sample, approximately $1 \mathrm{~mm}^{3}$ of the tissue was cut and dried at $55^{\circ} \mathrm{C}$ for $30 \mathrm{~min}$. After drying, $100 \mu \mathrm{L}$ of the lysis buffer was added to the dry tissue $(98 \mu \mathrm{L}$ of $10 \mathrm{mM}$ Tris- $\mathrm{HCl}, \mathrm{pH} 8.0,0.5 \%$ of SDS and $0.5 \mathrm{mM}$ of EDTA, with addition of $2 \mu \mathrm{L}$ of Proteinase $\mathrm{K}, 20 \mathrm{mg} \mathrm{mL}^{-1}$ ) and incubated for $2 \mathrm{~h}$ at $55^{\circ} \mathrm{C}$ with occasional shaking. After lysis, the lysate was mixed with $50 \mu \mathrm{L}$ of ammonium acetate $(7.5 \mathrm{M})$ and put on $+4{ }^{\circ} \mathrm{C}$ for half an hour to precipitate the proteins. The samples were centrifuged for $6 \mathrm{~min}$ at 12,000 $\mathrm{g}$ and the supernatant was transferred to new tubes, while the white precipitate was discarded. To each sample $1 \mu \mathrm{L}$ of glycogen $\left(20 \mathrm{mg} \mathrm{mL}^{-1}\right)$ was added to help to precipitate DNA, followed by the addition of $120 \mu \mathrm{L}$ of isopropanol and subsequently mixed by flicking the tubes 20 times. After the centrifugation step of $10 \mathrm{~min}$ at $12,000 \mathrm{~g}$, isopropanol was poured out of the tube while the DNA pellet was left at the bottom. The DNA pellet was washed with $300 \mu \mathrm{L}$ of $70 \%$ ethanol by inverting the tube 20 times. After the washing step, the tube was centrifuged $3 \mathrm{~min}$ at 12,000 $\mathrm{g}$, the ethanol was discarded, and the pellet was air-dried. After drying, the DNA pellet was dissolved in $50 \mu \mathrm{L}$ of TE buffer [16,17].
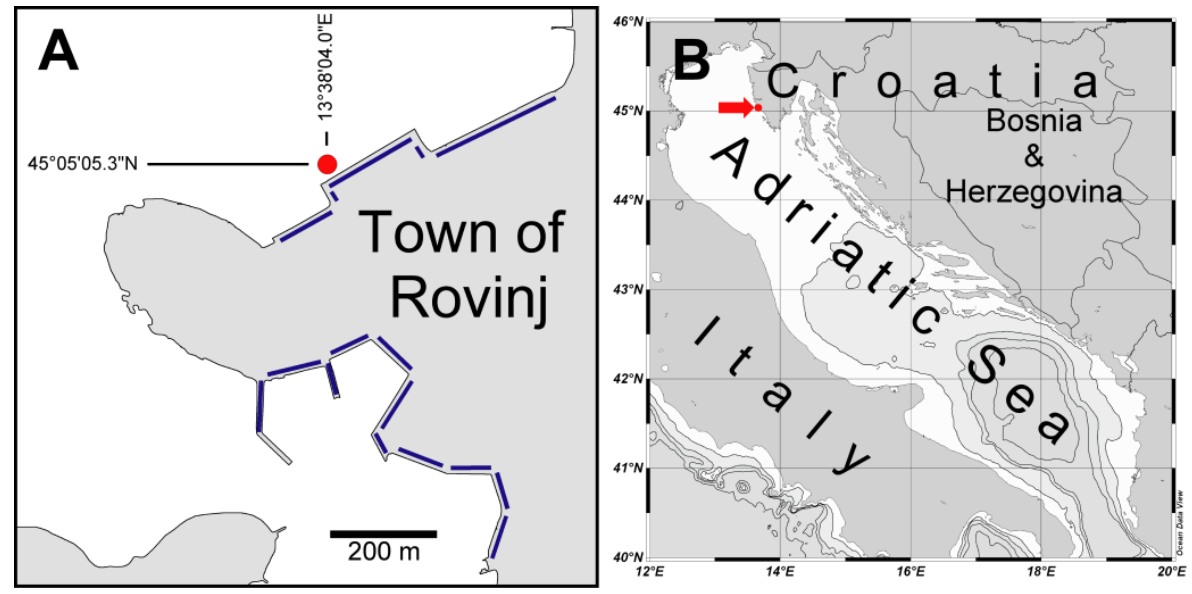

Figure 1. (A) Location of the collection of Aurelia pseudosolida sp. nov. in the town of Rovinj (red dot on the left figure). Dark blue lines denote part of the coast visually examined from the shore for Aurelia medusae. In total, $1750 \mathrm{~m}$ of shore was examined and 275 individuals of Aurelia solida were found and one individual of Aurelia pseudosolida sp. nov. (B) Location of the town of Rovinj (red dot pointed to by the red arrow) in the context of the Adriatic Sea.

Three regions were PCR-amplified and sequenced: 18S-ITS1-5.8S-ITS2-28S, mitochondrial subunit I of cytochrome oxidase (COI) and mitochondrial 16S. The18S-ITS1-5.8S-ITS2$28 \mathrm{~S}$ region was sequenced using four overlapping fragments amplified with the following primer pairs: app2f-omm1100r (sequenced by internal primers oiko800r and aur550f), 500f-n1800r (sequenced by internal primers aur750f and 1300f), its5-ilits2r (sequenced by internal primers aur58sr and aur28s200r) and 28sinf-28sr (sequenced by primer 28sinf and 
internal primer aur28s600r) (Table 1). Mitochondrial subunit I of cytochrome oxidase was sequenced using the primer pair LCO1490-HCO2198, and 16S was sequenced using primer pair SHB-SHA2 (Table 1).

Table 1. Primers marked with $X$ were used for PCR and/or sequencing (Seq) of 18S-ITS1-5.8SITS2-28S region and COI and 16S gene fragments of Aurelia solida and Aurelia pseudosolida sp. nov. individuals.

\begin{tabular}{|c|c|c|c|c|}
\hline Primer & $5^{\prime}-3^{\prime}$ Sequence & PCR & Seq & Reference \\
\hline \multicolumn{5}{|c|}{ 18S-ITS1-5.8S-ITS2-28S } \\
\hline app2f & ATCTGGTTGATCCTGCCAGT & $x$ & & \multirow{2}{*}{ Modified from Medlin et al., 1988 [18] } \\
\hline n1800r & GATCCTTCCGCAGGTTCACCT & $X$ & & \\
\hline its5 & GGAAGTAAAAGTCGTAACAAGG & $x$ & & \multirow{2}{*}{$\begin{array}{l}\text { White et al., } 1990 \text { [19] } \\
\text { Modified from Ye et al., 2015 [20] }\end{array}$} \\
\hline $28 \mathrm{sr}$ & TGGTTCGATTAGTCTTTCGCC & $x$ & & \\
\hline $500 f$ & ATTGGAGGGCAAGTCTGGTG & $x$ & & \multirow{2}{*}{ Universal } \\
\hline $1300 \mathrm{f}$ & GGTGGTGCATGGCCGTTCTTAG & & $X$ & \\
\hline omm1100r & ATCCAAGAATTTCACCTCTAACG & $x$ & & \multirow{10}{*}{ This study } \\
\hline oiko800r & CTGCTTTGAACACTCTAATTTTTTC & & $X$ & \\
\hline aur550f & GGTAATTCCAGCTCCAATAGC & & $x$ & \\
\hline aur750f & TGTGCTCTTAACTGAGTGTGC & & $X$ & \\
\hline omm1100r & ATCCAAGAATTTCACCTCTAACG & $x$ & & \\
\hline aur58sr & TTGACATGACGCTCAGACAG & & $x$ & \\
\hline $28 \operatorname{sinf}$ & ACCCGCTGAATTTAAGCATATTA & $X$ & $X$ & \\
\hline ilitis2r & GCATTCCCAAACAACCCGACTC & $x$ & & \\
\hline aur28s200r & TCTCTGATGTGCTGTTCCAAG & & $X$ & \\
\hline aur28s600r & TCTAGGCACGAGTGGATATAAC & & $x$ & \\
\hline \multicolumn{5}{|l|}{ COI } \\
\hline LCO1490 & GGTCAACAAATCATAAAGATATTGG & $X$ & $X$ & \multirow{2}{*}{ Folmer et al., 1994 [21] } \\
\hline $\mathrm{HCO} 2198$ & TAAACTTCAGGGTGACCAAAAAATCA & $x$ & $x$ & \\
\hline \multicolumn{5}{|l|}{$16 \mathrm{~S}$} \\
\hline SHB & TCGACTGTTTACCAAAAACATA & $x$ & & $\begin{array}{c}\text { Cunningham and Buss (1993) [22]; } \\
\text { Schuchert (2005) [23] }\end{array}$ \\
\hline SHA2 & ATTGTAGATAGAAACCTTCCTG & $x$ & & Batistić and Garić, 2016 [24] \\
\hline
\end{tabular}

The PCR was performed in a $25 \mu \mathrm{L}$ PCR mix containing $1 \times$ PCR buffer, $0.2 \mathrm{mM}$ of each dNTP, $3 \mathrm{mM} \mathrm{MgCl}_{2}, 0.2 \mu \mathrm{M}$ of each primer, $1.2 \mathrm{U}$ of Taq polymerase (NEB \#M0273) and $0.5 \mu \mathrm{L}$ of template DNA. All amplifications except for COI were performed using the same PCR programme with a 2 min denaturation step at $94{ }^{\circ} \mathrm{C}$, followed by 40 cycles of $94{ }^{\circ} \mathrm{C}$ for $15 \mathrm{~s}, 50^{\circ} \mathrm{C}$ for $30 \mathrm{~s}, 68^{\circ} \mathrm{C}$ for $1 \mathrm{~min}$ and a final extension step at $68^{\circ} \mathrm{C}$ for $7 \mathrm{~min}$. The COI fragment was amplified using a PCR programme with a 2 min denaturation step at $94{ }^{\circ} \mathrm{C}$, followed by 40 subsequent cycles of $94{ }^{\circ} \mathrm{C}$ for $20 \mathrm{~s}, 45^{\circ} \mathrm{C}$ for $1 \mathrm{~min}, 68^{\circ} \mathrm{C}$ for $1.5 \mathrm{~min}$ and a final extension step at $68^{\circ} \mathrm{C}$ for $5 \mathrm{~min}$. PCR products were sequenced by the company Macrogen. The obtained sequences were assembled in BioEdit (Ibis Biosciences). All obtained sequences were deposited at GenBank.

In total, 38 mitochondrial 16S rRNA sequences and 35 nuclear ITS1-5.8S sequences were used for the phylogenetic reconstruction. Two sequences were obtained in this study while others were obtained from GenBank. The alignments were made using MAFFT online service with the G-INS-1 method [25] (Alignments S1 and S3). Divergent and ambiguously aligned blocks were removed from the resulting alignments using Gblocks V0.91b [26] (Alignments S2 and S4), using the minimum number of sequences for a conserved position 20, minimum number of sequences for a flanking position 32, maximum number of contiguous nonconserved positions 8 , minimum length of a block 5 and allowed gap position of a half. Phylogenetic analysis was performed using the maximum likelihood method in MEGAX [27]. GTR + G was selected as the optimal model of evolution for the $16 \mathrm{~S}$ phylogeny, based on model selection tool implemented in MEGAX, and four discrete 
gamma categories were chosen. For the ITS1-5.8S phylogeny, T92 + G was chosen as the best model of evolution, with four discrete gamma categories. The resulting trees were tested by 1000 bootstrap replicates.

COI sequences of all the available described and genetic Aurelia species were aligned using ClustalW [28] (Alignment S5) and the K2P distance was calculated in MEGAX between Aurelia pseudosolida sp. nov. and other available Aurelia COI sequences in GenBank (Table S1), in order to determine if the distance between them is more than the expected species gap [29].

\section{Results}

\subsection{Collected Material}

About 1750 m of nearshore water in the town of Rovinj on 27 July 2020 was visually examined from the shore (Figure 1). In total, 275 individuals of Aurelia solida were recorded and one female individual of Aurelia pseudosolida sp. nov. At the same time a bloom of the ctenophore Mnemiopsis leidy was recorded (Figure 2). The Aurelia solida individuals were largely lethargic with very thick and firm mesoglea, thick and firm manubrium arms and with loss of marginal tentacles. One single specimen of Aurelia solida was found in good shape and condition (isolate ASP1), which was used for comparison to the Aurelia pseudosolida sp. nov. individual (isolate ASP2). The collected individual of Aurelia pseudosolida sp. nov. was in perfect condition, actively swimming (Videos S1 and S2) with the manubrium and with oral arms yellow from the numerous attached planulae.

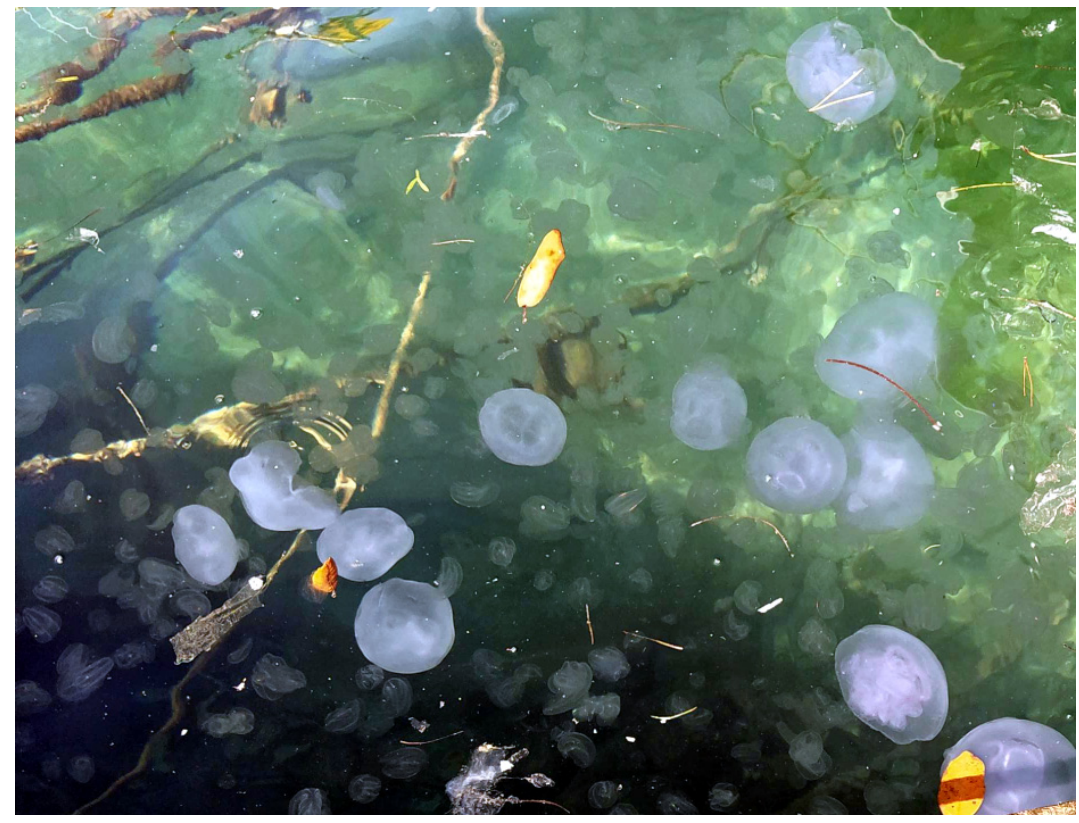

Figure 2. Combined bloom of Aurelia solida and Mnemiopsis leidy.

\subsection{DNA Analysis}

Sequences of the COI, 18S-ITS1-5.8S-ITS2-28S and 16S regions were obtained from five Aurelia solida individuals and one Aurelia pseudosolida sp. nov. individual. The sequences were deposited in GenBank under accession numbers MZ782091-MZ782096 (COI), MZ788652-MZ788653 (18S-ITS1-5.8S-ITS2-28S) and MZ788654-MZ788659 (16S), out of which sequences under the accession numbers MZ782092, MZ788652 and MZ788655 belong to Aurelia pseudosolida sp. nov. (Table 2). 
Table 2. List of obtained Aurelia sequences in this study.

\begin{tabular}{ccc}
\hline Species & Isolate & Accession Number \\
\hline 18S-ITS1- & & \\
5.8S-ITS2-28S & & \\
\hline Aurelia pseudosolida sp. nov. & ASP2 & MZ788652 \\
Aurelia solida & ASP6 & MZ788653 \\
\hline COI & & \\
\hline Aurelia pseudosolida sp. nov. & ASP2 & MZ782092 \\
Aurelia solida & ASP1 & MZ782091 \\
Aurelia solida & ASP3 & MZ782093 \\
Aurelia solida & ASP4 & MZ782094 \\
Aurelia solida & ASP5 & MZ782095 \\
Aurelia solida & ASP6 & \\
\hline 16S & & MZ788655 \\
\hline Aurelia pseudosolida sp. nov. & ASP2 & MZ788654 \\
Aurelia solida & ASP1 & MZ788656 \\
Aurelia solida & ASP3 & MZ788657 \\
Aurelia solida & ASP4 & MZ788658 \\
Aurelia solida & ASP5 & MZ788659 \\
Aurelia solida & ASP6 &
\end{tabular}

Phylogenetic analysis based on the 16S rRNA gene fragment showed that genus Aurelia contains two major clades (Figure 3). One clade is comprised of species Aurelia sp. 12, Aurelia sp. 13, Aurelia mianzani, Aurelia marginalis, Aurelia rara, Aurelia montyi, Aurelia smithsoniana and Aurelia cebimarensis, while majority of species are placed in another clade. The relationships between species within the clades are largely with low bootstrap supports. The ITS1-5.8S phylogeny also positions Aurelia pseudosolida sp. nov. as a distinct clade within other Aurelia species (Figure 3). When compared to other Aurelia species, the smallest COI K2P distance is between Aurelia pseudosolida sp. nov. and Aurelia hyalina, which is 0.14 . The largest found K2P distance, 0.27, is between Aurelia pseudosolida sp. nov. and Aurelia montyi, Aurelia ayla, Aurelia mozambica and Aurelia sp. 9 (Table S1).
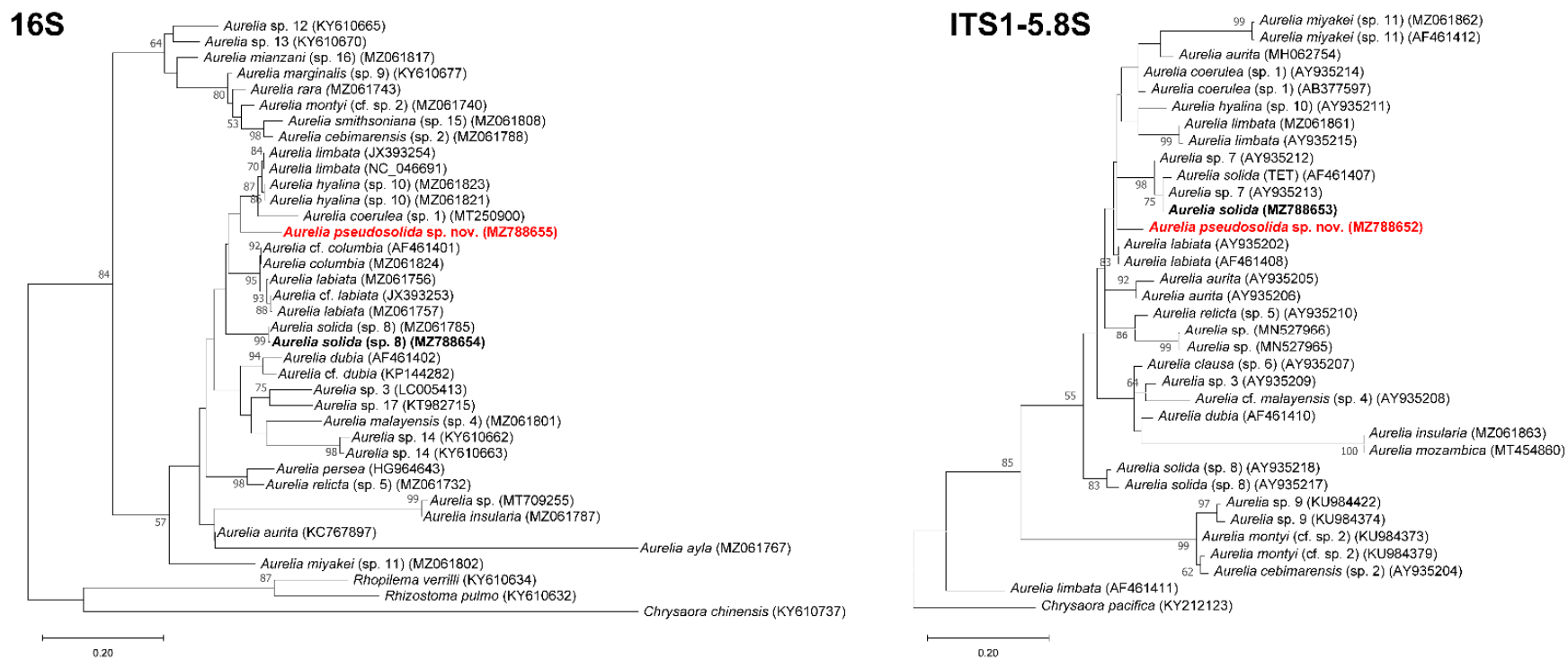

Figure 3. Maximum likelihood $16 \mathrm{~S}$ and ITS1-5.8S phylogenetic trees made using the GTR $+\mathrm{G}$ and T92 + G models of evolution, respectively, with four discrete gamma categories, with the position of Aurelia pseudosolida sp. nov. The trees were tested by 1000 bootstrap replicates. Bootstrap support values above 50 are shown next to the respective nodes. 


\subsection{Species Description}

Subclass: Discomedusae Haeckel, 1880.

Family: Ulmaridae Haeckel, 1880.

Genus: Aurelia Lamarck, 1816.

Aurelia pseudosolida Garić \& Batistić sp. nov.

Figures 4-6.

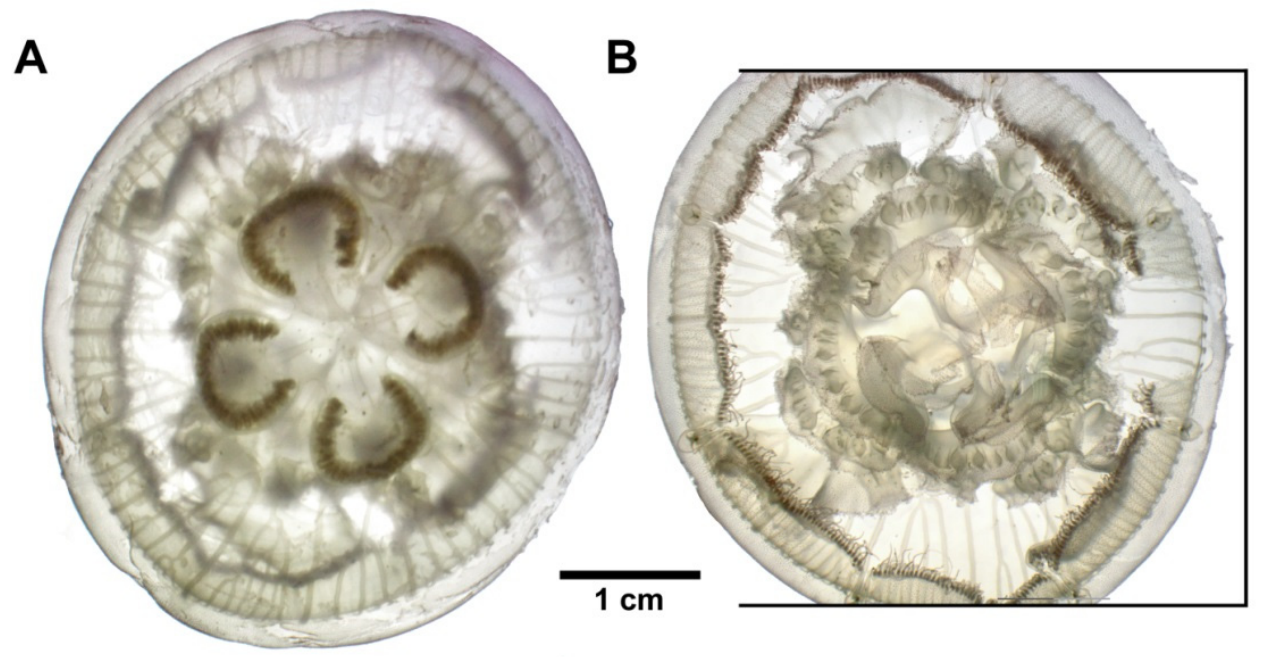

Figure 4. Aboral (A) and oral (B) side of A. pseudosolida sp. nov. On the right side of the each photograph a cutout in the umbrella can be seen. The tissue in the cutout was used for the DNA extraction.

Material examined: One female specimen (holotype) collected at the surface in the town of Rovinj on 27 July 2020 at the coordinates $45^{\circ} 05^{\prime} 05.3^{\prime \prime} \mathrm{N}$ and $13^{\circ} 38^{\prime} 04.4^{\prime \prime} \mathrm{E}$. The specimen is deposited in the Natural History Museum Dubrovnik (Dubrovnik, Croatia) under the inventory number PMD-2414.

Holotype: The bell is circular, dome shaped, with eight equally spaced rhopalia. Mesogleia thickness is $11 \mathrm{~mm}$. The species is characterized by 8 indentations at each of 8 rhopalia and 8 smaller, secondary indentations midway between the rhopalia, making in total 16 velar lobes (Figure 4). The rhopalium is covered with a beak-shaped hood, which together with the rhopaliar lappets remind of a cephalopod beak (Figures 5E and 6C). The rhopalium has pronounced rhopaliar lappets with a sensory organ at a variable angle from nearly $90^{\circ}$ to $45^{\circ}$ in relation to the bell surface. Only an ectodermal ocellus is present with pigment granules forming two bent stripes (Figure 6A,B). There is a relatively low number of large tentacles (on average 43 per quadrant) at the bell margin. The estimated bell diameter is $49 \mathrm{~mm}$ (the medusa was not relaxed so the bell diameter was estimated). The mesoglea is thick. The distance between the most proximate points of the opposite gastric cavities is $7.6 \mathrm{~mm}$, while the distance between most distal points of the opposite gastric cavities is $21.8 \mathrm{~mm}$. The subgenital pore diameter is $2 \mathrm{~mm}$ (Figure $5 \mathrm{~B}$ ).

Publication LSID: http:/ / zoobank.org/E762EA9D-FF4F-496D-8B29-BA5D34D0C943.

Diagnosis: The oral arms are the most distinguishing feature of this species. They are very folded, in a zig-zag manner, along the proximodistal axis and towards the inner side of the bell (Figure 5D). The oral arms contain large brooding chambers in the form of lacunae of the oral arms, which contain numerous yellow planulae (Figure 5C,D), unlike the oral arms of Aurelia solida, which contain leaf-like structures (Figure 7E,F). The oral arms are very stiff in the proximal and medial part and get loose only at the distal part that does not contain brooding chambers. The species resembles Aurelia labiata in the pyramidal shape of the manubrium and backward-hanging oral arms. The gonads are yellowish. The species possesses a relatively low number of large tentacles, about 43 per quadrant, unlike about the 80 small tentacles per quadrant of Aurelia solida (isolate ASP1). The sensory 
organ of the rhopalium is as in Aurelia solida. The gonads are horseshoe shaped, unlike in Aurelia solida, which possesses tear (or pear)-shaped gonads (Figure 7A). Aurelia pseudosolida sp. nov. possesses few anastomoses and all the canals are anastomosed. Since Aurelia pseudosolida sp. nov. is genetically distinct from all the so-far sequenced Aurelia species, it is important to establish its difference from unsequenced Aurelia species; so far, those are only $A$. maldivensis, $A$. colpota and A. vitiana. Aurelia pseudosolida sp. nov. possesses a single origin of interradial canals per quadrant (Figure 5A) while A. solida, A. maldivensis [30] and Aurelia colpota [31] have multiple origins. Aurelia vitiana seems to have a single origin of interradial canals per quadrant, the same as Aurelia pseudosolida sp. nov., but based on drawings by Agassiz and Mayer [32] it possesses quite simple oral arms and about 65 tentacles per quadrant.

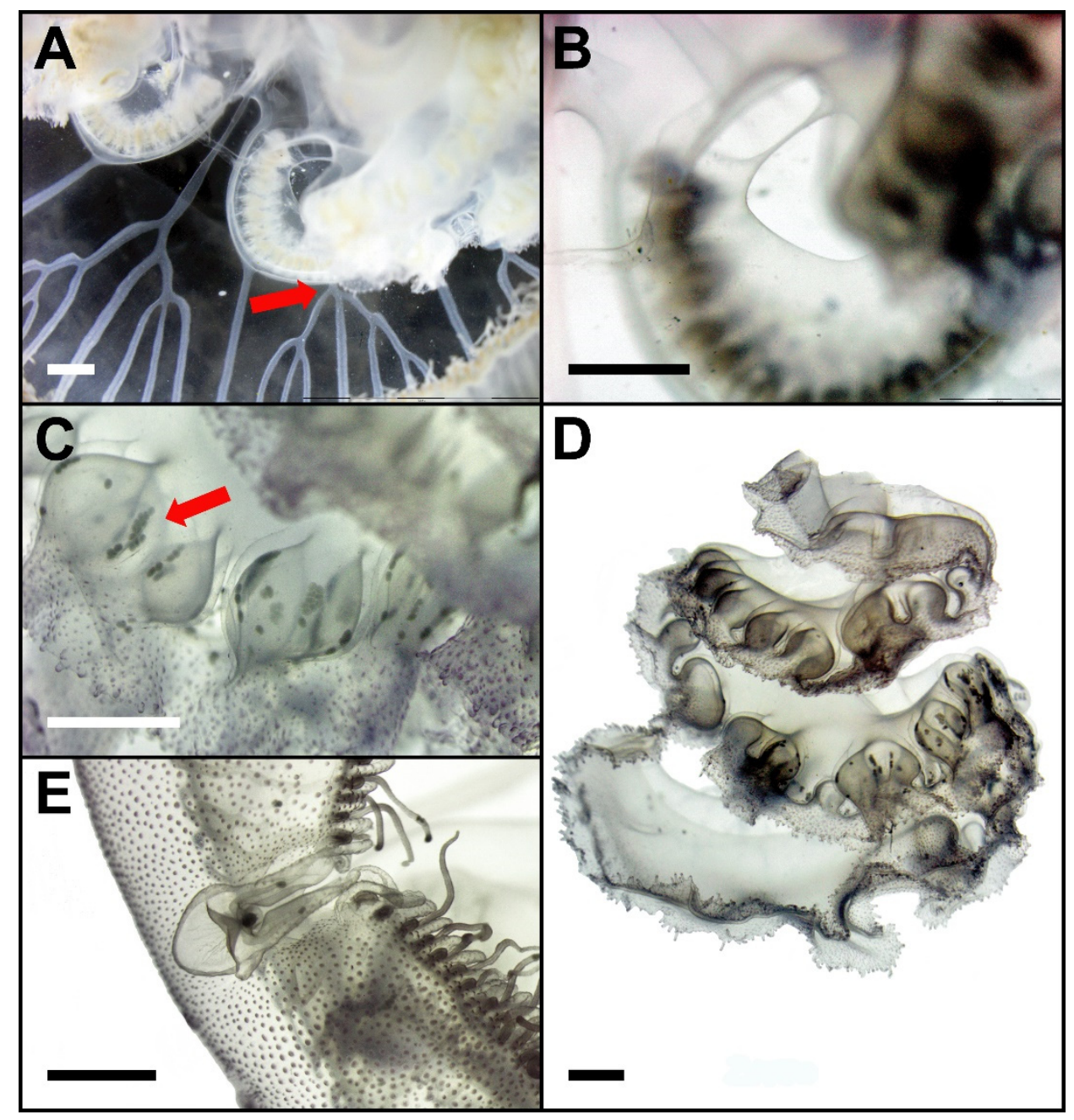

Figure 5. (A) portion of the bell photographed from the subumbrellar side. The red arrow points to the single origin of the interradial canal. (B) Subgenital pore. (C) Part of an oral arm with brooding chambers. The red arrow points to planulae inside the brooding chamber; (D) Amputated oral arm. (E) Portion of the bell margin with a rhopalium. All bars are $2 \mathrm{~mm}$ in length. 

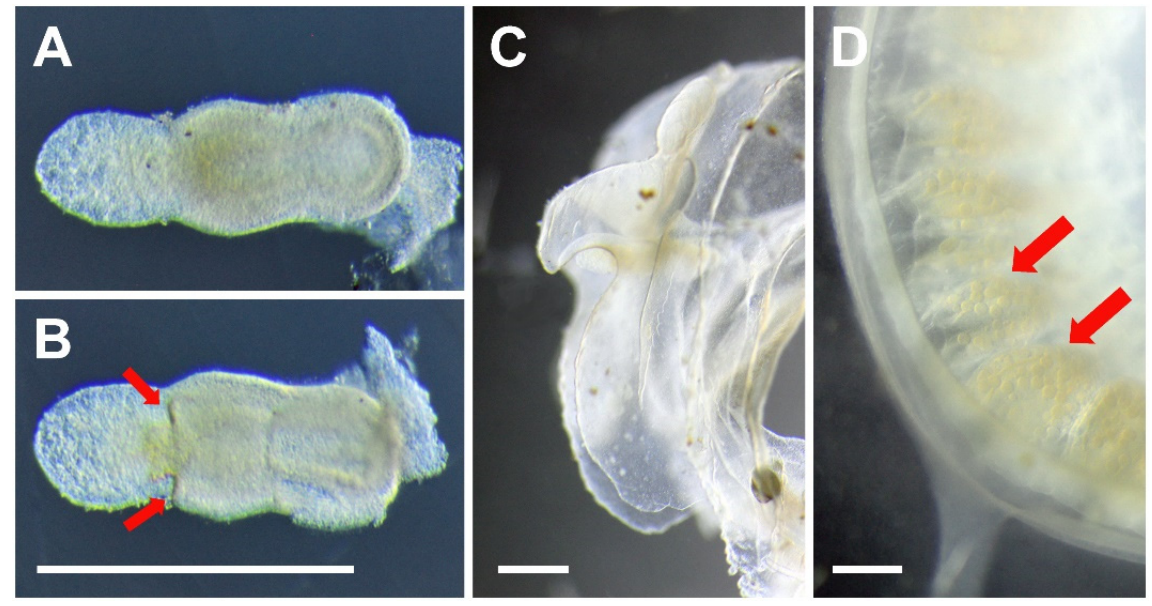

Figure 6. Aurelia pseudosolida sp. nov. (A) Oral side of the sensory organ. (B) Aboral side of the sensory organ. (C) Lateral view of the rhopalium. (D) Gonads with yellow ova. All bars are $500 \mu \mathrm{m}$ in length.
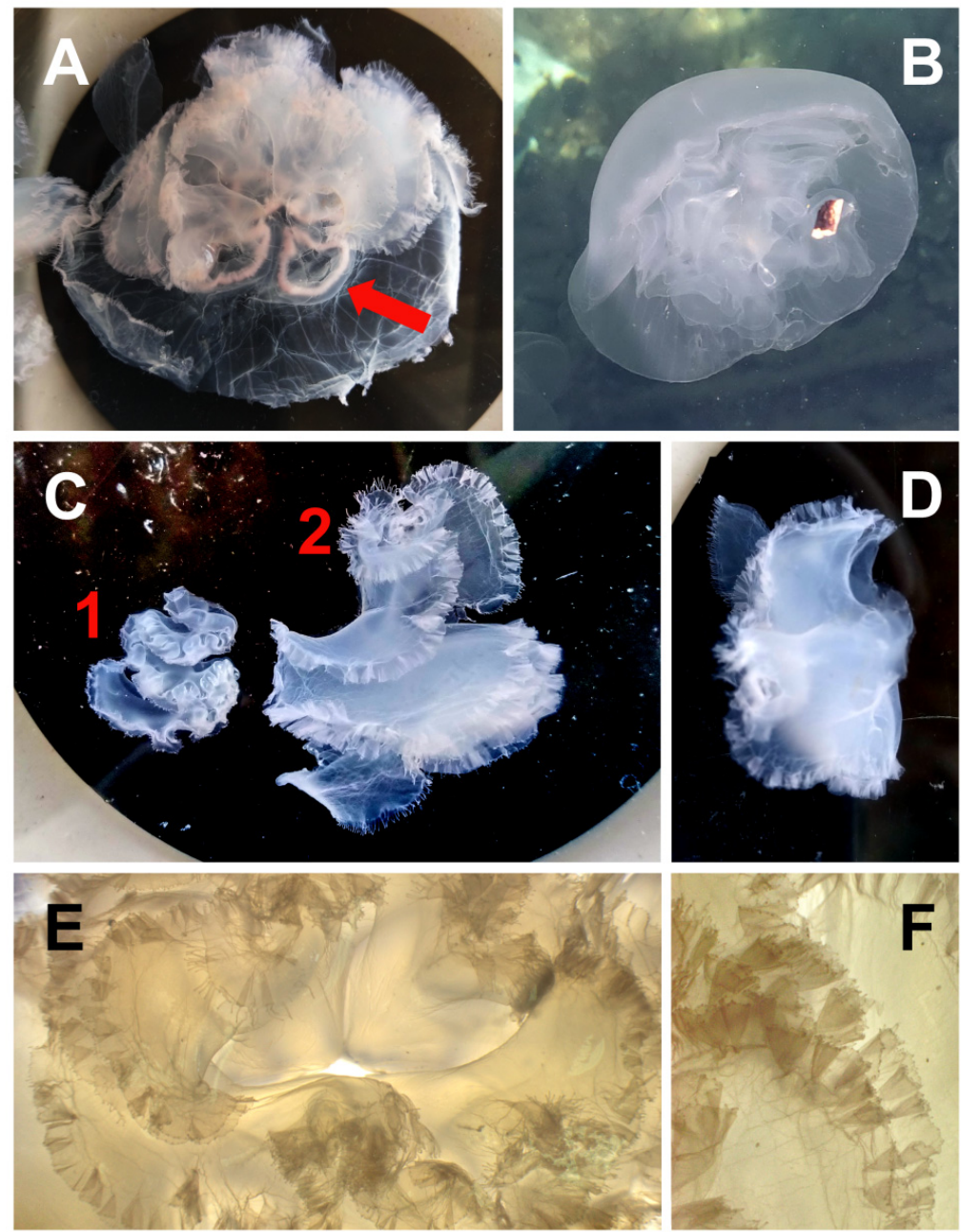

Figure 7. (A) Aurelia solida, (isolate ASP1), with the red arrow pointing to the tear-shaped (or pear-shaped) gonads. (B) Aurelia solida with flower-like appearance of the manubrium arms. (C) 1amputated oral arm of Aurelia pseudosolida sp. nov.; 2-amputated oral arm of Aurelia solida (isolate ASP1). (D) Aboral view of the amputated oral arm of Aurelia solida (isolate ASP1). (E) Manubrium opening of Aurelia solida (isolate ASP1). (F) Detail of the leaf-like structures at the margin of the oral arms of Aurelia solida (isolate ASP1). 
Etymology: Aurelia pseudosolida sp. nov. is named after Aurelia solida, since it has been found in the middle of bloom of Aurelia solida.

\section{Discussion}

Given the fact that we found only one individual of Aurelia pseudosolida sp. nov., extensive genetic (mitochondrial and nuclear) and morphological data were given to firmly confirm its establishment as a new species. All the data corroborate the distinctiveness of Aurelia pseudosolida sp. nov. Both $16 \mathrm{~S}$ and ITS1-5.8S phylogenies position Aurelia pseudosolida sp. nov. as a distinctive clade within the genus Aurelia. K2P distances of COI show that the closest distance between Aurelia pseudosolida sp. nov. and another Aurelia species is between Aurelia pseudosolida sp. nov. and Aurelia hyalina, this being 0.14. Such a K2P distance is about 2.5 times larger than the largest within-species K2P distance in a medusozoan, as found by Ortman et al. [29]. Such a K2P distance represents further firm evidence of Aurelia pseudosolida sp. nov. being a new species of Aurelia. In previous investigations, much importance was put on continuous morphometric characters as an objective means of species delimitation among Aurelia species, while meristic characters fell slightly out of focus $[6,11]$. Such an approach can be valuable when many individuals of an unidentified population are available or when unique meristic or qualitative characters, which can be used for species delimitation, are not present; however, regarding time consumption, it can easily approach genetic techniques. On the other hand, one single, unique distinctive qualitative character is invaluable in the quick determination of a species. With this in mind, we provided detailed photographs of Aurelia pseudosolida sp. nov., with emphasis on the manubrium arms. The distinctive morphology of the manubrium arms was not considered in much detail in recent descriptions of Aurelia species [6,11], but in the case of Aurelia pseudosolida sp. nov. and Aurelia solida it can be used for quick determination of these species in the Adriatic. For 20 years many Aurelia species were only known as genetic species. Without a systematic attempt to characterize them morphologically, no formal description could be made. In 2021, Lawley et al. [15] decided to promote genetic characters as identification characters for species description. The argument was made that a combination of continuous morphometric and meristic characters was not sufficient to delimit Aurelia species, which are prone to morphological variability [15]. This approach was positive in a way that formal names are given to sequences, which would help metabarcoding studies, but for practical field work it will still require a follow-up string of papers that would need to try to find appropriate meristic or qualitative characters for quick species determination; otherwise, every individual of such species would take days or weeks to determine based on its genetic sequence.

Aurelia pseudosolida sp. nov. was found in the North Adriatic amongst combined blooms of Aurelia solida and Mnemiopsis leidy in summer 2020. The North Adriatic is the most productive area of the Adriatic sea [33] and it is known for recurring blooms of gelatinous organisms [34]. In recent decades there have been occurrences of blooms of nonindigenous species in the North Adriatic, such as bloom of Muggiaea atlantica in 1997 [35], Mawia benovici in 2013 [36], Mnemiopsis leidy in 2016 [37] and 2017 [38], and onwards. The exact moment of arrival of Aurelia solida in the North Adriatic is unknown but it is currently considered to be a likely Lessepsian migrant [6-8]. First proof of Aurelia solida being the blooming Aurelia in the North Adriatic was given by Ramšak et al. in 2012 [8]. Aurelia solida occurs every year in the North Adriatic with a different magnitude of occurrence [39]. The Adriatic Sea is influenced by decadal changes in circulation regimes in the Ionian, which affect the advection of water masses of different properties as well as the arrival of non-indigenous organisms [40,41]. Such a dynamic nature of the exchange of water masses might partially explain the bloom dynamics of gelatinous species in the North Adriatic [42] as well as the relatively large number of newly described gelatinous zooplankton species in such a well-investigated basin $[36,43,44]$. It seems that the North Adriatic might be one of the Mediterranean hotspots where non-indigenous gelatinous species can bloom and be more easily detected. With this in mind, the finding of a single individual of another new 
species of gelatinous zooplankton of unknown ecology and blooming potential calls for continuous monitoring of the North Adriatic as a sensitive area of the Adriatic Sea.

The description of Aurelia pseudosolida sp. nov. and, recently, Aurelia mozambica [11], Aurelia ayla and Aurelia insularia [15], indicate that the diversity of the genus Aurelia is likely much larger than currently known. Due to the fact that Aurelia polyps can be transported by ships, it is to be expected that more and more gelatinous species would be found in hotspot areas such as the North Adriatic, where non-indigenous species can reach higher numbers, which would enable their detection.

Supplementary Materials: The following are available online at https:/ /www.mdpi.com/article/10 .3390/w14020135/s1, Alignment S1: 16S alignment, Alignment S2: 16S alignment gblocks refined, Alignment S3: ITS1-5.8S alignment, Alignment S4: ITS1-5.8S alignment gblocks refined, Alignment S5: COI alignment, Table S1: K2P distances between available Aurelia COI sequences, Video S1: Aurelia pseudosolida sp. nov. swimming, Video S2: Aurelia pseudosolida sp. nov. swimming.

Author Contributions: Specimen collection, genetic analysis, R.G.; morphological analysis, species description, writing, R.G and M.B. All authors have read and agreed to the published version of the manuscript.

Funding: This research was funded by Croatian Science Foundation, under projects DiVMAd (IP-2019-04-9043) and SpaTeGen (UIP-2020-02-3907).

Data Availability Statement: The data presented in this study are available in the Supplementary Material.

Acknowledgments: We would like to thank the Laboratory for evolutionary ecology, Center for marine research (CIM), Ruđer Bošković Institute, for logistic support, as the material for the study was collected during our visit to the CIM.

Conflicts of Interest: The authors declare no conflict of interest. The funders had no role in the design of the study; in the collection, analyses, or interpretation of data; in the writing of the manuscript, or in the decision to publish the results.

\section{References}

1. Purcell, J.E. Predation on Zooplankton by Large Jellyfish, Aurelia Labiata, Cyanea Capillata and Aequorea Aequorea, in Prince William Sound, Alaska. Mar. Ecol. Prog. Ser. 2003, 246, 137-152. [CrossRef]

2. Purcell, J.E. Predation on Fish Eggs and Larvae by Pelagic Cnidarians and Ctenophores. Bull. Mar. Sci. 1985, 37, 739-755.

3. Purcell, J.E.; Sturdevant, M.V. Prey Selection and Dietary Overlap among Zooplanktivorous Jellyfish and Juvenile Fishes in Prince William Sound, Alaska. Mar. Ecol. Prog. Ser. 2001, 210, 67-83. [CrossRef]

4. Ghermandi, A.; Galil, B.; Gowdy, J.; Nunes, P.A.L.D. Jellyfish Outbreak Impacts on Recreation in the Mediterranean Sea: Welfare Estimates from a Socioeconomic Pilot Survey in Israel. Mar. Econ. Policy Relat. Ecosyst. Serv. Lessons World's Reg. Seas. 2015, 11, 140-147. [CrossRef]

5. Kim, D.-H.; Seo, J.-N.; Yoon, W.-D.; Suh, Y.-S. Estimating the Economic Damage Caused by Jellyfish to Fisheries in Korea. Fish. Sci. 2012, 78, 1147-1152. [CrossRef]

6. Scorrano, S.; Aglieri, G.; Boero, F.; Dawson, M.N.; Piraino, S. Unmasking Aurelia Species in the Mediterranean Sea: An Integrative Morphometric and Molecular Approach. Zool. J. Linn. Soc. 2017, 180, 243-267. [CrossRef]

7. Schroth, W.; Jarms, G.; Streit, B.; Schierwater, B. Speciation and Phylogeography in the Cosmopolitan Marine Moon Jelly, Aurelia Sp. BMC Evol. Biol. 2002, 2, 1. [CrossRef] [PubMed]

8. Ramšak, A.; Venko, K.; Malej, A. Comparative Phylogeography of Meroplanktonic Species, Aurelia Spp. and Rhizostoma Pulmo (Cnidaria: Scyphozoa) in European Seas. Hydrobiologia 2012, 690, 69-80. [CrossRef]

9. Dawson, M.N.; Jacobs, D.K. Molecular Evidence for Cryptic Species of Aurelia Aurita (Cnidaria, Scyphozoa). Biol. Bull. 2001, 200, 92-96. [CrossRef]

10. Collins, A.G.; Jarms, G.; Morandini, A.C. World List of Scyphozoa. Aurelia Lamarck. 1816. Available online: https://www. marinespecies.org/aphia.php? $\mathrm{p}=$ taxdetails\&id=135263 (accessed on 4 November 2021).

11. Brown, M.; Scorrano, S.; Kuplik, Z.; Kuyper, D.; Ras, V.; Thibault, D.; Engelbrecht, A.; Gibbons, M.J. A New Macromedusa from the Coast of Mozambique: Aurelia Mozambica sp. nov. (Scyphozoa: Ulmaridae). Zootaxa 2021, 4933, 263-276. [CrossRef]

12. Gershwin, L. Systematics and Biogeography of the Jellyfish Aurelia Labiata (Cnidaria: Scyphozoa). Biol. Bull. 2001, 201, 104-119. [CrossRef]

13. Dawson, M.N.; Gupta, A.S.; England, M.H. Coupled Biophysical Global Ocean Model and Molecular Genetic Analyses Identify Multiple Introductions of Cryptogenic Species. Proc. Natl. Acad. Sci. USA 2005, 102, 11968. [CrossRef] [PubMed] 
14. Gómez Daglio, L.; Dawson, M.N. Species Richness of Jellyfishes (Scyphozoa: Discomedusae) in the Tropical Eastern Pacific: Missed Taxa, Molecules, and Morphology Match in a Biodiversity Hotspot. Invertebr. Syst. 2017, 31, 635-663. [CrossRef]

15. Lawley, J.W.; Gamero-Mora, E.; Maronna, M.M.; Chiaverano, L.M.; Stampar, S.N.; Hopcroft, R.R.; Collins, A.G.; Morandini, A.C. The Importance of Molecular Characters When Morphological Variability Hinders Diagnosability: Systematics of the Moon Jellyfish Genus Aurelia (Cnidaria: Scyphozoa). PeerJ 2021, 9, e11954. [CrossRef] [PubMed]

16. Slusarenko, A.J. A Rapid Miniprep for the Isolation of Total DNA from Agrobacterium Tumefaciens. Plant Mol. Biol. Report. 1990, 8 , 249-252. [CrossRef]

17. Osterburg, H.H.; Allen, J.K.; Finch, C.E. The Use of Ammonium Acetate in the Precipitation of Ribonucleic Acid. Biochem. J. 1975, 147, 367-368. [CrossRef]

18. Medlin, L.; Elwood, H.J.; Stickel, S.; Sogin, M.L. The Characterization of Enzymatically Amplified Eukaryotic 16S-like RRNACoding Regions. Gene 1988, 71, 491-499. [CrossRef]

19. White, T.; Bruns, T.; Lee, S.; Taylor, J. Amplification and Direct Sequencing of Fungal Ribosomal RNA Genes for Phylogenetics. In PCR Protocols: A Guide to Methods and Applications; Innis, M., Gelfand, D., Sninsky, J., White, T., Eds.; Academic Press, Inc.: San Diego, CA, USA, 1990; pp. 315-322.

20. Ye, W.; Zeng, Y.; Kerns, J. Molecular Characterisation and Diagnosis of Root-Knot Nematodes (Meloidogyne Spp.) from Turfgrasses in North Carolina, USA. PLoS ONE 2015, 10, e0143556. [CrossRef]

21. Folmer, O.; Black, M.; Hoeh, W.; Lutz, R.; Vrijenhoek, R. DNA Primers for Amplification of Mitochondrial Cytochrome c Oxidase Subunit I from Diverse Metazoan Invertebrates. Mol. Mar. Biol. Biotechnol. 1994, 3, 294-299.

22. Cunningham, C.W.; Buss, L.W. Molecular Evidence for Multiple Episodes of Paedomorphosis in the Family Hydractiniidae. Biochem. Syst. Ecol. 1993, 21, 57-69. [CrossRef]

23. Schuchert, P. Species Boundaries in the Hydrozoan Genus Coryne. Mol. Phylogenet. Evol. 2005, 36, 194-199. [CrossRef]

24. Batistić, M.; Garić, R. The Case of Bougainvillia Triestina Hartlaub 1911 (Hydrozoa, Cnidaria): A 100-Year-Long Struggle for Recognition. Mar. Ecol. 2016, 37, 145-154. [CrossRef]

25. Katoh, K.; Rozewicki, J.; Yamada, K.D. MAFFT Online Service: Multiple Sequence Alignment, Interactive Sequence Choice and Visualization. Brief. Bioinform. 2019, 20, 1160-1166. [CrossRef] [PubMed]

26. Castresana, J. Selection of Conserved Blocks from Multiple Alignments for Their Use in Phylogenetic Analysis. Mol. Biol. Evol. 2000, 17, 540-552. [CrossRef] [PubMed]

27. Kumar, S.; Stecher, G.; Li, M.; Knyaz, C.; Tamura, K. MEGA X: Molecular Evolutionary Genetics Analysis across Computing Platforms. Mol. Biol. Evol. 2018, 35, 1547-1549. [CrossRef]

28. Thompson, J.D.; Higgins, D.G.; Gibson, T.J. CLUSTAL W: Improving the Sensitivity of Progressive Multiple Sequence Alignment through Sequence Weighting, Position-Specific Gap Penalties and Weight Matrix Choice. Nucleic Acids Res. 1994, 22, 4673-4680. [CrossRef] [PubMed]

29. Ortman, B.D.; Bucklin, A.; Pagès, F.; Youngbluth, M. DNA Barcoding the Medusozoa Using MtCOI. Species Divers. Mar. Zooplankton 2010, 57, 2148-2156. [CrossRef]

30. Bigelow, H.B. Medusae from the Maldive Islands. Bull. Mus. Comp. Zool. Harv. Coll. 1904, 39, $245-269$.

31. Brandt, J.-F. Prodromus Descriptionis Animalium Ab H. Mertensio Observatorum: Fascic. I. Polypos, Acalephas Discophoras et Siphonophoras, Nec Non Echinodermata Continens. Recueil des Actes de la Séance Publique de l'Académie Impériale des Sciences de St. Pétersbourg 1835, 1834, 201-275.

32. Agassiz, A.; Mayer, A.G. Acalephs from the Fiji Islands. Bull. Mus. Comp. Zoöl. Harv. Coll. 1899, 32, 157-189.

33. Benović, A.; Fonda-Umani, S.; Malej, A.; Specchi, M. Net-Zooplankton Biomass of the Adriatic Sea. Mar. Biol. 1984, 79, 209-218. [CrossRef]

34. Kogovšek, T.; Bogunović, B.; Malej, A. Recurrence of Bloom-Forming Scyphomedusae: Wavelet Analysis of a 200-Year Time Series. Hydrobiologia 2010, 645, 81-96. [CrossRef]

35. Kršinić, F.; Njire, J. An Invasion by Muggiaea Atlantica Cunningham 1892 in the Northern Adriatic Sea in the Summer of 1997 and the Fate of Small Copepods. Acta Adriat. 2001, 42, 49-59.

36. Piraino, S.; Aglieri, G.; Martell, L.; Mazzoldi, C.; Melli, V.; Milisenda, G.; Scorrano, S.; Boero, F. Pelagia Benovici sp. nov. (Cnidaria, Scyphozoa): A New Jellyfish in the Mediterranean Sea. Zootaxa 2014, 3794, 455-468. [CrossRef] [PubMed]

37. Malej, A.; Tirelli, V.; Lučić, D.; Paliaga, P.; Vodopivec, M.; Goruppi, A.; Ancona, S.; Benzi, M.; Bettoso, N.; Camatti, E.; et al. Mnemiopsis Leidyi in the Northern Adriatic: Here to Stay? J. Sea Res. 2017, 124. [CrossRef]

38. Fiori, E.; Benzi, M.; Ferrari, C.R.; Mazziotti, C. Zooplankton Community Structure before and after Mnemiopsis Leidyi Arrival. J. Plankton Res. 2019, 41, 803-820. [CrossRef]

39. Malej, A.; Kogovšek, T.; Ramšak, A.; Catenacci, L. Blooms and Population Dynamics of Moon Jellyfish in the Northern Adriatic Cah. Biol. Mar. 2012, 53, 337-342.

40. Batistić, M.; Garić, R.; Molinero, J.C. Interannual Variations in Adriatic Sea Zooplankton Mirror Shifts in Circulation Regimes in the Ionian Sea. Clim. Res. 2014, 61, 231-240. [CrossRef]

41. Gačić, M.; Borzelli, G.L.E.; Civitarese, G.; Cardin, V.; Yari, S. Can Internal Processes Sustain Reversals of the Ocean Upper Circulation? The Ionian Sea Example. Geophys. Res. Lett. 2010, 37. [CrossRef] 
42. Civitarese, G.; Gačić, M.; Lipizer, M.; Eusebi Borzelli, G.L. On the Impact of the Bimodal Oscillating System (BiOS) on the Biogeochemistry and Biology of the Adriatic and Ionian Seas (Eastern Mediterranean). Biogeosciences 2010, 7, 3987-3997. [CrossRef]

43. Garić, R.; Batistić, M. Description of Brooksia Lacromae sp. nov. (Tunicata, Thaliacea) from the Adriatic Sea. Eur. J. Taxon. 2016, 196. [CrossRef]

44. Garić, R.; Batistić, M. Fritillaria Ragusina sp. nov., a New Species of Appendicularia (Tunicata) from the Adriatic Sea. J. Mar. Biol. Assoc. UK 2011, 91, 555-559. [CrossRef] 